\title{
Documents show French government is still looking to 'streamline' CNRS
}

Paris. Thousands of researchers from the Centre National de la Recherche Scientifique (CNRS), the largest basic-research organization in Europe, took to the streets across France last week to protest against a decision by Guy Aubert, the agency's new director-general, that researchers spend no more than 60 per cent of the funds they had been allocated for this year.

The protests were fuelled not only by the last-minute budget revision, but also by uncertainty over the future of the agency itself. One proposal contained in an unpublished government circular could reduce the number ofCNRS scientific departments from seven to three, for example, and its laboratories from 1,300 to as few as 400 , with the control of many laboratories passing directly to universities.

From Marseilles to Orsay, last week saw a flurry of emergency meetings by researchers, amid an atmosphere of rebellion not seen since the last conservative government slashed research funding in 1986. Feelings were running particularly high as the government had already cut the research budget (excluding salaries) by 8 per cent in June (see Nature 369, 511; 1994).

Most researchers agree that CNRS needs to act to avert an imminent financial crisis.

\section{'Seaborgium' fails to win approval}

San Francisco. Researchers at the Lawrence Berkeley Laboratory (LBL) in California will continue to call element 106 seaborgium, after Glenn T. Seaborg, the Nobel prizewinning chemist, even though the International Union of Pure and Applied Chemistry (IUPAC) has rejected the name. IUPAC has decided that it is not prepared to name new elements after living scientists.

The team that created and identified element 106 in 1974 announced its decision to name it after Seaborg, who shared in the discovery of plutonium and nine other transuranium elements, at a meeting of the American Chemical Society (ACS) in March. The ACS's nomenclature committee subsequently accepted the name.

But seaborgium is not among the nine names recommended last month for elements 101 to 109 by IUPAC's Commission on Nomenclature of Inorganic Chemistry. The 20 chemists from 12 countries on the committee said they had decided elements should not be named after living people, and gave element 106 the name rutherfordium after Ernest Rutherford, the New Zealand physicist who discovered the atom.

"The majority of the commission felt it was necessary to have the perspective of history in relation to these discoveries before such a decision was made," the commission wrote in the announcement, to be published in the December issue of Pure and Applied Chemistry.

In general, the commission used names proposed by the three major German, Russian and US groups involved in the nine discoveries - although not in the order suggested. But Albert Ghiorso, the senior nuclear scientist emeritus at Lawrence Berkeley Laboratory (LBL) who led the team that discovered element 106 , said he felt that seaborgium had fallen victim to

political horsetrading.

Ghiorso says that it was the first time that a discoverer of an element had not been allowed to have his or her name attached to the element concerned. He added that Seaborg was the obvious person to name the element after.

Seaborg himself, who won the 1951 Nobel prize in chemistry with E. M. McMillan for his work on the chemistry of the transuranium elements, says that he is disappointed by the decision, which he calls "illogical". He points out that some of his accomplishments took place more than 50 years ago, clearly withstanding IUPAC's test of time.

The IUPAC committee has proposed that elements 101, 102 and 103 be named mendelevium, nobelium and lawrencium respectively. It also recommended two Russian-proposed names of dubnium (after Dubna, near Moscow) and joliotium (after the physicists Frédéric Joliot) for elements 104 and 105.

All the proposed names are subject to ratification by the IUPAC Council at its meeting in Guildford, England, in August 1995.

Sally Lehrman
But there has been outrage at the demand that they spend no more than 60 per cent of the funds they were allocated for 1994. Many have already spent this proportion, and therefore have no more money until the end of the year.

In a letter to Aubert, the five directors of the Institut Jacques Monod in Paris, which has already spent 75 per cent of its allocated budget for this year, demanded that he withdraw the revision. Its repercussions, they warn, would extend well beyond the end of the year.

Vice-chancellors and laboratory heads have similarly warned that the budget revision would "partially or totally paralyse" research. Scientists have said that this would mean that they will be unable to buy reagents to keep cell cultures alive or radioisotopes for DNA sequencing.

At Orsay, outside Paris, where several major CNRS laboratories stand to have FFr20 million (US\$3.8 million) less than expected to spend - equivalent to running expenses for two months - researchers have said they will be forced to send postgraduate students to "work in the library" for the remainder of the year.

Aubert has said that it was "not easy" to take such measures so soon after being appointed, and that he understands that researchers may feel in a state of shock. "Previously oblivious to the financial situation, they have taken off their blindfolds, only to see the wall that is waiting for them," he said in an interview with Le Monde.

The "wall" in question is a FFr550 million gap in the CNRS's finances which has accumulated over the past few years because annual payments from the state have failed to match promises made in the budget.

But trade unions argue that the CNRS has access to a 'reserve' of unspent funds that exceeds this deficit. They claim that Aubert is only taking such harsh action because he badly needs a "war-chest" to finance his proposed reforms of CNRS, and that CNRS has already taken out a bank loan to finance the proposed reforms.

Earlier this year, François Fillon, the minister for higher education and research, appeared to have abandoned wide-ranging reforms of the research system that the government had previously been contemplating, after strong resistance from researchers (see Nature 368, 675; 1994). But many of the main elements have now reappeared.

For example, an internal circular at the science ministry, dated 12 October, suggests reforms that would eventually transform the CNRS from a research organization directly employing thousands of 